\title{
常時微動計測を活用した擬洋風 建築物の耐震性能評価
}

\section{SEISMIC PERFORMANCE EVALUATION OF GI-YOFU ARCHITECTURE USING MICROTREMOR MEASUREMENT}

\section{山田 明- $* 1$ 金野章子 -2}

キーワード :

常時微動計測, 耐震診断, 擬洋風木造建築

Keywords:

Microtremor measurement, Seismic diagnosis, Gi-yofu architecture

\section{Akira YAMADA $-* 1 \quad$ Shoko KANO $* 1$}

In this paper, we discuss a seismic performance evaluation technique of a wooden important cultural property building. The building is a Gi-yofu architecture which exists in Bingo, Hiroshima. We drafted structural drawings based on assumptions, because the structural details of the building are unknown. On the other hand, we carried out a microtremor measurements and clarified the vibration characteristics of the building. Furthermore, we examined and verified the technique to judge the validity of the structural assumption from the measurement result.

\section{1.はじめに}

我が国には文化的価值を有する木造建築物が数多く現存する。こ れらを保存・活用するため, 文化財建築物の耐震診断と耐震補強に対 する社会的要求は非常に高い。他方, 意匠性を維持する必要もあり, 耐震補強設計には一般の住宅以上に注意が払われると考えられる。

角陸らは，重要文化財建築物の耐震補強における意思決定につい て検討し, 構造設計者の課題を, 構造設計者が現場に足を運ぶととも に様々な可能性について検討することが重要であると指摘している 1)。その一方, 文化財建築物の多くでは, 安易な解体・復旧や調査の ための点検口設置は困難であり，改修等の機会に詳細調查が実施さ れる場合が多い。したがって，改修すべきかを検討する段階では，建 物全体にわたっての詳細な構造調査は困難と言える。構造設計の観 点からすれば, 不明な点は仮定せざるを得ない。仮定が多ければ多い ほど現実との乘離が生じ, 設計期間中は試行錯誤の連続を伴い, 改修 工事が終了するまで継続することもあり得る。したがって, 改修工事 の構造設計には新築時の設計以上の配慮と労力を伴うと思われる。

ところで, 常時微動計測は, 構造物の振動特性を非破壊で知ること ができる調査である。常時微動では振動の振幅が微小なため, 地震動 のような大振幅時の挙動を評価することに否定的な考えも見られる ものの, 計測が簡単なため, 微動と地震動に対する振動特性の相関性 に着目した研究が数多く実施されている。例えば, 濱ら 2 , 海原ら ${ }^{3}$ は重要文化財建築物の改修に伴う解体過程において, 建築物の常時 微動計測を行い, 振動特性の検討を行っている。杉野ら 4)は, 常時微 動計測から得られる固有振動数の振幅依存性を考慮した伝統木造建 築物の最大地震応答を推定する方法について検討している。木造住 宅に目を向ければ，田端ら 5)，柳澤ら 6)，西塔ら 7)は，常時微動計測 を耐震診断に応用する方法について検討している。

文化財やそれに類する建築物の多くは，いわゆる伝統木造建築物 に該当し，とりわけ和風建築物が大多数を占める例えば 8,9$)$ と思われる が, 他方で洋風建築物も存在する。洋風建築物を対象とした常時微動 計測は和風建築物ほどに数多くはないが，事例で言えば文献 10-13)
等の研究があり, 振動特性のデータベース化や改修に伴う振動特性 の変化について検討されている。

このように，文化財を含めた木造建築物を対象とした耐震診断・耐 震補強の機運は高い。事実, 実例も多く, 常時微動計測も積極的に実 施されている。しかし, 既往事例の多くは, 振動特性や振動モードの 同定，構造耐力との相関や地震応答の推定に主眼を置いたものであ る。構造設計の観点から, 常時微動計測を耐震診断上の不明点を推定 し，計算仮定の信頼性を高める材料に用いるための手法について検 討された事例は，筆者の知る限りほとんどない。

そのような中，筆者らは擬洋風建築物の重要文化財の耐震性能に ついて調査する機会を得た。非破壊で調査するため, 構造上の重要な 仕様を詳細に確認することが困難だったため, 既存図面や施工写真 を確認するとともに天井裏の調查を行い，仮定の下で構造図を作成 した。仮定による構造図を用いて, 現況の耐震性を評価した。その一 方で常時微動計測も行い, 評価時の仮定の妥当性を検証した。本論は 個別物件における検討ではあるが，手法には普遍性があり，耐震改修 時の構造検討における常時微動計測の有用性と手法を示寸点におい て，意義あるものと考える。

\section{2. 建物概要}

本研究の対象は, 広島県府中市に建つ 2 階建の擬洋風建築物であ る。1903 年に郡役所庁舎として竣工し, 1926 年の郡役所廃止後は県 の出先諸事務所として使用された。1975 年に取り壊しが計画された ものの, 市民による保存運動により移築保存され，現在は歴史民俗資 料館として利用されている。建物外観の意匠的価值は䇋工時のまま 維持され，1977 年に市の重要有形文化財に指定された。その一方, 現在は老朽化が著しい状態にある。また，耐震性能については，移築 時の法令に対して検討されたものの，現行法による適合状態は確認 されていない。改修履歴については，2001 年芸予地震時に外壁と基 礎に亀裂が生じ, 補修されている。また, 1996 年に天井が改修され ている。建物外観を写真 1 , 概略を表 1 ，平面を図 1 に示す。

\footnotetext{
福山大学工学部建築学科 准教授 ·博士 (工学) 


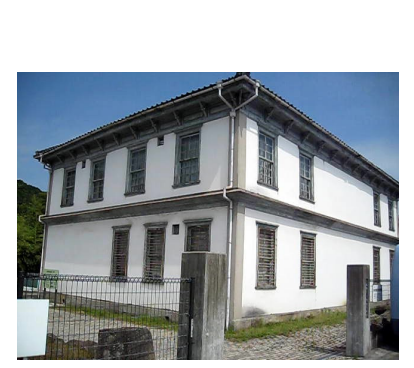

写真 1 建物外観
表 1 建物概要

\begin{tabular}{|c|c|c|}
\hline \multirow{3}{*}{$\begin{array}{l}\text { 面 } \\
\text { 積 }\end{array}$} & 1 & 階 $238.588 \mathrm{~m}^{2}$ \\
\hline & 2 & 階 $231.868 \mathrm{~m}^{2}$ \\
\hline & 延 & $470.456 \mathrm{~m}^{2}$ \\
\hline & 階 数 & 2 階建て \\
\hline \multicolumn{3}{|c|}{\begin{tabular}{l|l} 
階 & $\mathrm{GL} \sim 1 \mathrm{~F} \mathrm{~L} 0.73 \mathrm{~m}$ \\
\end{tabular}} \\
\hline \multirow{2}{*}{ 陀高 } & 1 & 階 $3.640 \mathrm{~m}$ \\
\hline & 2 & 階 $3.250 \mathrm{~m}$ \\
\hline \multirow{3}{*}{ 仕 } & & 根日本瓦幕き（土井荤き下地） \\
\hline & & 壁ラスモルタル下地漆喰塗り \\
\hline & 内 & 壁ラスボード漆哴塗り \\
\hline \multirow{2}{*}{ 様 } & 床 & ニードルパンチカーペット張り \\
\hline & 天 & 井プラスターボード \\
\hline
\end{tabular}
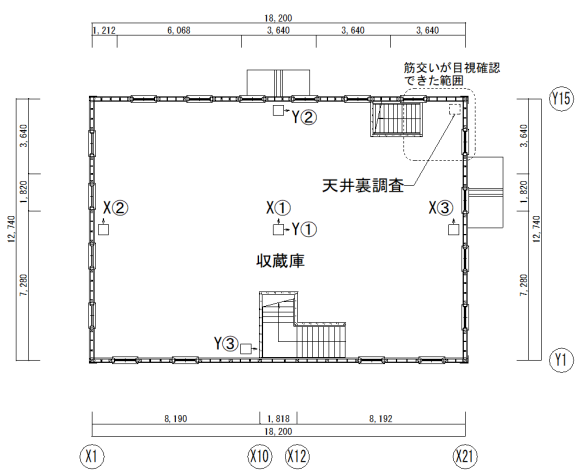

2階
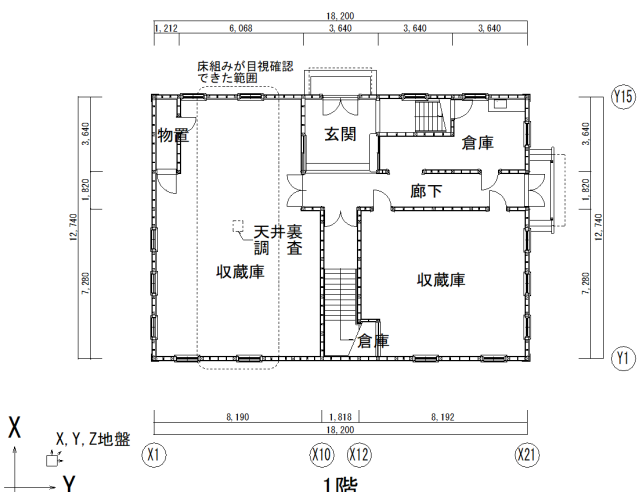

注） 2 階の $\square$ は計測位置とそのチャンネルを示す。

図 1 平面図

\section{3. 現地調査と構造図の作成}

建物の状態を把握するため, 現地調査を実施した。移築時の建築図 と古写真は現存しており，現地にて図面と照合した。また，1，2 階 の天井点検口から 2 階床組, 小屋組の状態を目視で確認した。

既存図面には構造図が添付されていない。平面図には筋かいの記 号, 断面, 配置場所だけが示されており, それによると, 片筋かい, 断面 $50 \mathrm{~mm} \times 150 \mathrm{~mm}$, 配置場所は外壁のみである。サーモグラフィカ メラを用い, 建物全体で筋かいの有無を確認したが, 確認できなかっ た。そこで, 2 階天井点検口から目視したところ, 点検口付近で図面 に記載された筋かいを確認することができ, 断面の大きさも確認で きた。しかし，片筋かいか両筋かいかの違いまでは確認できなかった。

既存資料と現地調査結果から構造図を作成した。軸組図を図 2 に 示す。なお，前述の通り，不明な点は仮定により作成した。

\section{4. 常時微動計測}

\section{1 計測方法}

2 階床上で, 剛床仮定の成立の判断および床のねじれを測定するた
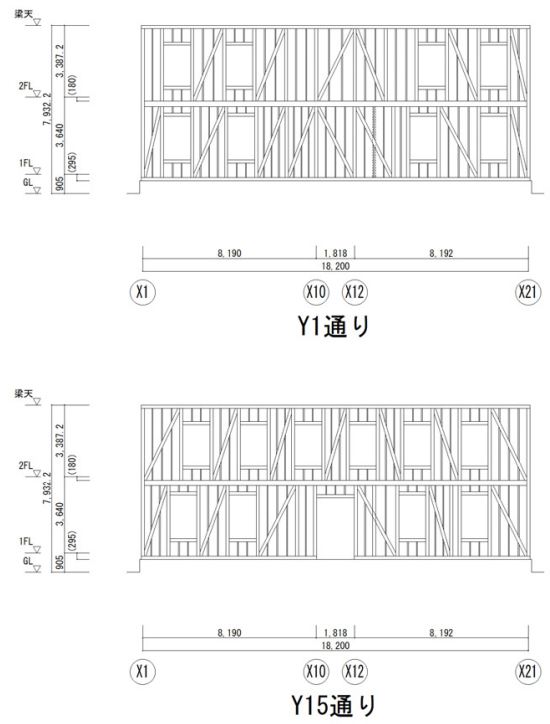

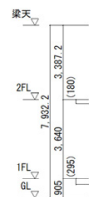
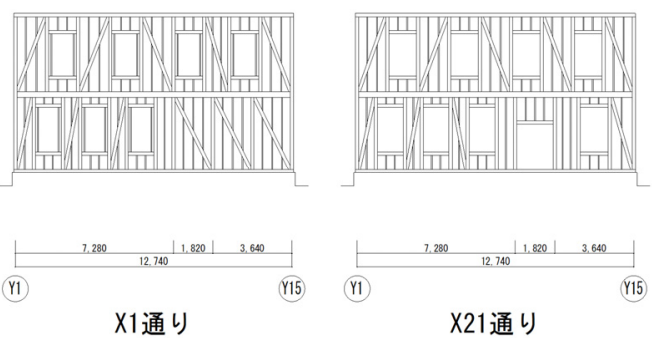

図 2 軸組図

めに， $X, Y$ の各方向について重心 1 か所と建物両側の外壁近傍 2 か 所の計 3 か所で常時微動の同時計測を行なう。さらに，地盤条件を 判断するため地盤の $X, Y, Z$ 方向の同時計測も行なう。計測位置は図 1 に付記（2 階平面図中の(1)〜3) した。

計測機器はサーボ型速度計（VSE-15D，(株)東京測振）とし，常時 微動の速度を計測する。サンプリング振動数は $100 \mathrm{~Hz}$, 計測時間は 500 秒とする。

\section{2 計測結果}

（1）地盤種別の推定

地盤種別を推定するために，大町ら 14)の手法を参考に，次の要領 で H/V スペクトル比を計算する。

1）地盤の 500 秒間（50,000 個）の計測データから安定した数值列 を，1区間につき 20 秒間（2,000 個）だけ，水平・鉛直の 3 成分に ついて 10 区間切り取る。

2) 切り取った数值列の前後に均等数の 0 を追加して 4,096 個の数值 列にし, 高速フーリエ変換によりフーリエ振幅スペクトルを計算し， ハニング・ウィンドウによる平滑化を 10 回施す。

3)各成分のフーリエ振幅スペクトルを平均化し, 次式により $\mathrm{H} / \mathrm{V}$ ス ペクトル比 $R_{S}(\omega)$ を求める。

$$
R_{S}(\omega)=\frac{\sqrt{\left|H_{1}(i \omega)\right|^{2}+\left|H_{2}(i \omega)\right|^{2}}}{|V(i \omega)|}
$$

ここで, $\left|H_{1}(i \omega)\right|,\left|H_{2}(i \omega)\right|$ は水平 2 方向のフーリエ振幅スペクト

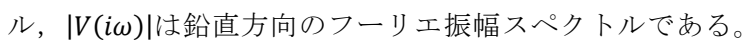

以上の方法によって得られた $R_{S}(\omega)$ を図 3 に示す。同図からは明 瞭なピークは認められない。なお， 10 区間の個々の $R_{S}(\omega)$ につて 


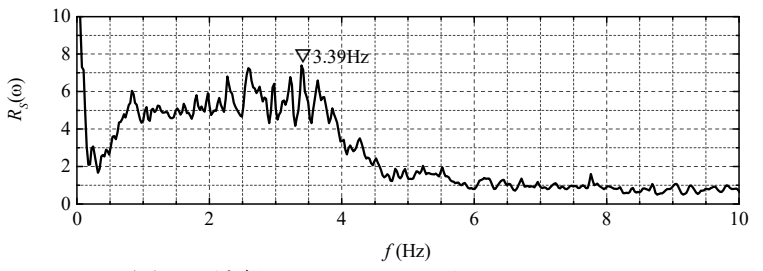

図 3 地盤の $\mathrm{H} / \mathrm{V}$ スペクトル比, $R_{S}(\omega)$

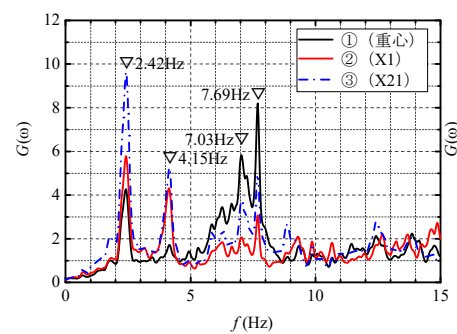

(a) $X$ 方向

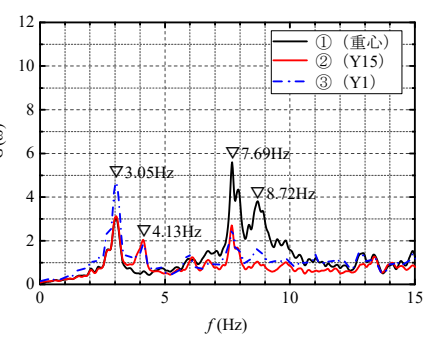

(b) $Y$ 方向
図 4 伝達関数, $G(\omega)$

も同様の傾向であった。明瞭なピークが認められない場合の判断方 法として，大町ら 14)は，基本的には最大ピークをとる振動数を卓越 振動数の候補とするとしている。そこで, 最大をとる $3.39 \mathrm{~Hz} \quad(0.29$ 秒）を地盤の卓越振動数（卓越周期 $T_{G}$ ) とした。これは，第一種地盤 の条件 $\left(T_{G} \leq 0.2\right.$ 秒 $)$ をわずかに満足せず, 第二種地盤 $\left(0.2\right.$ 秒 $<T_{G} \leq$ 0.75 秒）に該当する。他方, 国立研究開発法人防災科学技術研究所が 公開している地震ハザードステーションによると, 敷地の表層地盤 における $30 \mathrm{~m}$ 平均 $\mathrm{S}$ 波速度は $776 \mathrm{~m} / \mathrm{s}$ とされており, それから $T_{G}$ を 求めると, $T_{G}=0.15$ 秒となり, 第一種地盤に該当する。両者の結果か ら，ここでは，当該地盤を第一種地盤に該当すると判断した。

（2）建物の固有振動数と振動モード

次の要領で伝達関数を計算し 15$)$ ，建物の固有振動数を同定する。

1) 床上および地盤の計測データを 20 秒間（2,000 個）ずつの 25 区

間に分割する。なお，最初と最後の 4,000 個のデータにはノイズが 多く含まれているため，3 区間目から 23 区間目の 21 区間につい て計算を行なう。

2) 各区間の数值列の前後に均等数の 0 を追加して 4,096 個の数值列 にし, 高速フーリエ変換を行なう。

3)各区間について，地盤と床のクロススペクトル $S_{i o}(\omega)$, 地盤のパ ワースペクトル $S_{i i}(\omega)$ を計算し，次式により各区間の伝達関数 $G(\omega)$ 求める。

$$
G(\omega)=\frac{S_{i o}(\omega)}{S_{i i}(\omega)}
$$

4) 得られた $G(\omega)$ を平均化し, さらに，ハニング・ウィンドウによる 平滑化を 10 回施す。

以上の方法によって得られた $X, Y$ 方向 $G(\omega)$ を図 4(a), (b)に示す。 図中には, 重心(1), 建物両側(2), (3)の $G(\omega)$ を示している。同図(a)か ら, $X$ 方向では $2.42,4.15,7.03,7.69 \mathrm{~Hz}$, 同図(b)から $Y$ 方向では 3.05 , $4.13,7.69,8.72 \mathrm{~Hz}$ の振動数がそれぞれ卓越していることが分かる。

これらの振動数におけるモードを確認するために，卓越振動数前 後 $0.5 \mathrm{~Hz}$ でバタワース型のバンドパスフィルターを施し, 基線補正 して積分した $X, Y$ 方向の変位波形を図 5(a),(b)に示す。なお，波形を 見やすくするため縦軸を適宜拡大し，目盛と単位の表示は略した。

同図(a)より, 最上段の波形(バンド幅 $2.0-3.0 \mathrm{~Hz}$, 固有振動数 $2.42 \mathrm{~Hz}$ )
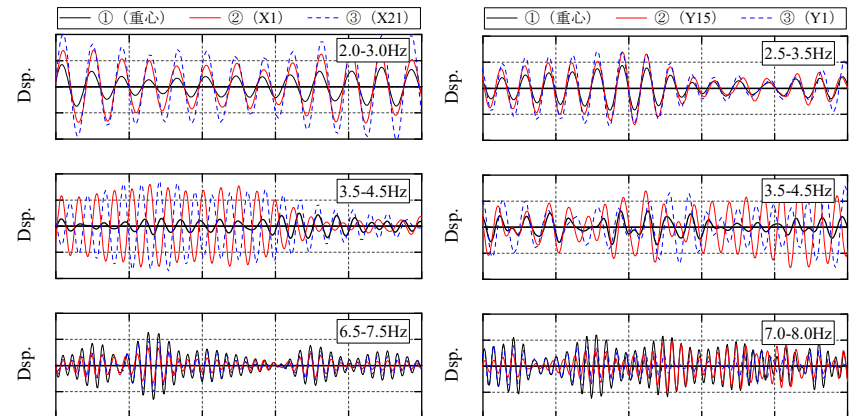

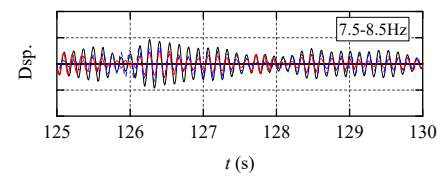

(a) $X$ 方向

図 5 変位波形

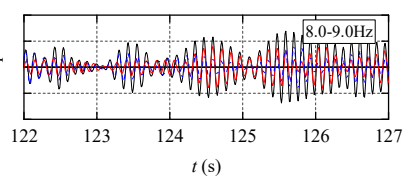

(b) $Y$ 方向

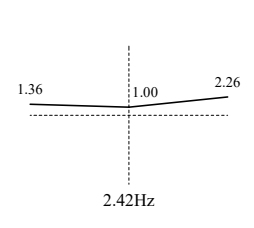

(a) 1 次

$x$ 方向 1 次

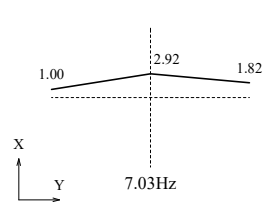

(d)4 次

$X$ 方向 2 次

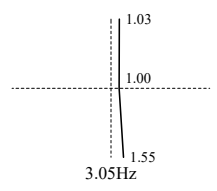

(b) 2 次

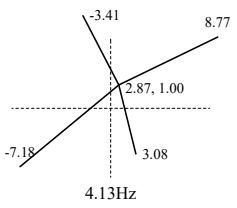

(c)3 次
$Y$ 方向 1 次

ねじれ 1 次

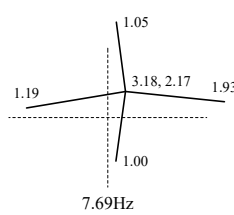

(e) 5 次

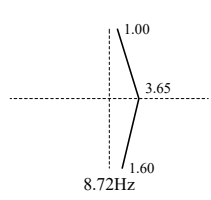

(f)6 次
$Y$ 方向 2 次

図 6 固有モード

では，(1)，(2)，(3)とも同位相の併進モードであるが，振幅が異なって いることから，剛床になっていないことが分かる。2 段目 $(3.5-4.5 \mathrm{~Hz}$, $4.15 \mathrm{~Hz}$ ) では，(2)と(3)が逆位相で振幅がほぼ同じであることから，ね じれモードであると推察される。3 段目 $(6.5-7.5 \mathrm{~Hz}, 7.03 \mathrm{~Hz})$ と 4 段 目（7.5-8.5Hz, 7.69Hz） は波形の形状が類似しており，独立したモー ドとなっていない。

同図(b)より，最上段の波形 $(2.5-3.5 \mathrm{~Hz}, 3.05 \mathrm{~Hz})$ は, $X$ 方向と同様, 併進モードであるが, 剛床となっていないことが分かる。2 段目（3.5$4.5 \mathrm{~Hz}, 4.13 \mathrm{~Hz}$ ) では，(2)と(3)が逆位相であり，X方向でも同じ振動数 の卓越が読み取れることから，全体のねじれモードであると判断で きる。3 段目 $(7.0-8.0 \mathrm{~Hz}, 7.69 \mathrm{~Hz})$ と 4 段目 $(8.0-9.0 \mathrm{~Hz}, 8.72 \mathrm{~Hz})$ は波 形の形状が類似しており，独立したモードとなっていないが，X方向 でも $7.69 \mathrm{~Hz}$ の卓越が見られることから，X，Yの両方向に関係したモ 一ドであって，おそらく，ねじれに関するものと思われる。以上の考 察に基づき, 伝達関数の值に波形の位相を考慮して符号をつけた 1〜 6 次の振動モードを図 6(a)〜 (f)に示す。

木造住宅を対象とした常時微動計測に関する既往調查は数多くあ り，例えば，鈴木ら 16)は，近畿地方にある既存住宅で実施した調查 において, 1 次固有振動数が $4.12 \sim 11.62 \mathrm{~Hz}$ であったとしている。岩 
井ら 17) は, 既往研究の対象となった木造建物の 1 次固有周期が 0.063 $\sim 0.50$ 秒（2.0 15.9Hz）に分布していたとしている。これらと比較 すると, 当該建物の 1 次固有振動数はかなり低く, したがって, 耐力 も低いことが予想される。

他方, 本研究に類似した洋風建築物の文化財を対象にした常時微 動計測については，一般住宅と比べれば数多くはないものの事例が

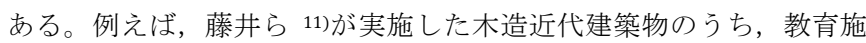
設や官公庁施設の 1 次固有振動数は 2 $5 \mathrm{~Hz}$ であったとしている。本 建物に類似した重要文化財の某庁舎の 1 次固有振動は約 $3.4 \mathrm{~Hz}$ であ ったとしている。これらと比較すると, 当該建物の固有振動数は事例 の範囲に収まっており，下限の方に位置している。

(3) 粘性減衰定数

$X, Y$ 方向の時刻歴データの自己相関関数から 1 次の粘性減衰定数 を同定する ${ }^{15)}$ 。

自己相関関数 $\rho$ は次式による。

$$
\rho_{j}=\frac{\sum_{m=0}^{N-1} v_{m} v_{m+j}}{\sum_{m=0}^{N-1} v_{m}^{2}}
$$

ここで，vは速度の時刻歴データ， $m$ は計測データのステップ， $j は$ ステップのずれ，Nは自己相関関数を計算するデータ数である。

ここでは，図5(a),(b)の最上段と同じバンド幅でフィルターをか けた速度波形について, $t=100 \sim 450$ 秒の 50 秒間隔 8 区間で 4096 個の数値列を抽出し, 自己相関関数を計算する。これを減衰自由振 動の理論式に最小二乗法によって 5 秒間について近似し, 1 次の固 有振動数 $f_{1}$ (固有円振動数 $\omega_{1}$ ) と粘性減衰定数 $h_{1}$ を同定する。自由 振動の理論式は次式による。

$$
v=e^{-h_{1} \omega_{1} t} \cos \sqrt{1-h_{1}^{2}} \omega_{1} t
$$

近似の一例を図 7 に図示し, 計算結果の一覧を表 2(a),(b)に示す。 表中の平均值より, $h_{1}$ は $X, Y$ 方向で差がなく, $h_{1} \fallingdotseq 0.03$ でることが分 かる。この結果は, 文献 16,17)の計測結果 (0.05 程度) と比べると 低め, 文献 11$)$ の計測結果 $(0.01 \sim 0.03)$ とは同程度になっている。 なお, 既往の研究では, RD 法により自己相関関数を求めている事 例が多いと思われるが, 本研究のように, フィルター処理した波形か ら自己相関関数を求めても減衰評価は十分に可能であった。

\section{5. 現況の耐震性能評価}

現況の建物の耐震性能を評価する。而震診断法には数多くの手法 があるが，ここでは，文献 18)の限界耐力計算を採用する。前述のよ うに, 当該建物の水平構面には剛床を仮定できないため, 鉛直構面別 のゾーニングによる診断が必要となると考えられる。また, 礼じれモ ードも確認されたから, 水平構面の変形や礼じれの影響を考慮でき るモデルでの計算が必要ではあるが, 水平構面の剛性・強度に関して は, 本調查では不明な点が多く, ここでは建物全体を 2 自由度系と みなして計算を行う。耐震性能を判断するクライテリアについては, 耐震要素が筋かいであることから, 損傷限界時 (中地震), 安全限界 時 (大地震) に対する限界変形角をそれぞれ 1/120 rad 以下, $1 / 30 \mathrm{rad}$ 以下とする。建設地の地震地域係数は $Z=0.9$ である。

前述のように, 移築後に改修が加えられており, 建物重量の根拠と なる下地, 仕上げの詳細を断定できない。また, 耐力壁の筋かいに関 する詳細な断定は難しい。そこで，適宜，仮定を導入する。

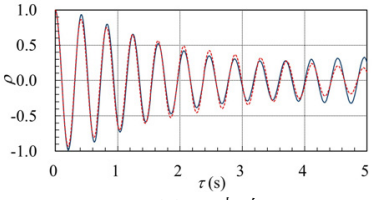

(a) $X$ 方向

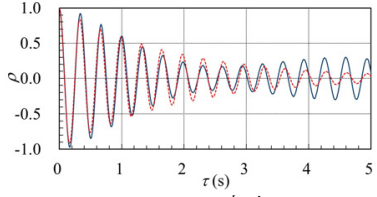

(b) $Y$ 方向
図 7 自己相関関数と減衰自由振動の近似の一例

(実線：自己相関関数, 破線：減衰自由振動)

\begin{tabular}{|c|c|c|c|c|c|c|c|c|c|}
\hline 時刻(s) & 100 & 150 & 200 & 250 & 300 & 350 & 400 & 450 & 平均値 \\
\hline$h$ & 0.025 & 0.016 & 0.035 & 0.030 & 0.033 & 0.028 & 0.033 & 0.023 & 0.028 \\
\hline$f(\mathrm{~Hz})$ & 2.473 & 2.475 & 2.343 & 2.428 & 2.428 & 2.434 & 2.413 & 2.428 & 2.428 \\
\hline \multicolumn{10}{|c|}{ (b) $Y$ 方向 } \\
\hline 時刻(s) & 100 & 150 & 200 & 250 & 300 & 350 & 400 & 450 & 平均値 \\
\hline$h$ & 0.049 & 0.025 & 0.022 & 0.026 & 0.024 & 0.027 & 0.030 & 0.028 & 0.029 \\
\hline$f(\mathrm{~Hz})$ & 3.017 & 3.014 & 2.976 & 2.981 & 3.143 & 3.079 & 2.954 & 3.039 & 3.025 \\
\hline
\end{tabular}

表 2 自己相関関数による 1 次固有振動数 $f_{1}$ と粘性減衰定数 $h_{1}$

\begin{tabular}{|c|c|c|}
\hline & 床面積当たりの荷重（単位 & \\
\hline 部位 & 仕 様 & 荷重 \\
\hline 屋根 & $\begin{array}{l}\text { 日本瓦草き } \\
\text { (土井莫下地, 軒の出 } 700 \mathrm{~mm} \text { ) }\end{array}$ & 2,400 \\
\hline 壁 & $\begin{array}{l}\text { 外：ラスモルタル下地漆喰塗り仕上げ } \\
\text { 内：ラスボード下地漆喰垈上げ } \\
\end{array}$ & 1,200 \\
\hline 内壁 & ラスボード下地漆喰塗仕上げ & 200 \\
\hline 床 & フリーリング (ベニア下地) & 600 \\
\hline 積載 & 展示室（教室相当） & 1,100 \\
\hline
\end{tabular}

\section{1 建物重量の仮定}

移築時の建築図に記載された仕上げ表を参考に, 文献 19)に記載さ れている床均し荷重に加え, 法令による積載荷重を用い, 簡易に計算 する。荷重一覧を表 3 に示す。表中の荷重は文献 20) に記載の床面積 当たり荷重とほぼ同じであり, 簡易でありながらも妥当であると判 断した。積載荷重については, 2 階は展示室であるものの, 数台の展 示パネルを設置しているのみであることから, 住宅程度の積載荷重 で十分と思われるが，ここでは教室相当の $1,100 \mathrm{~N} / \mathrm{m}^{2}$ を採用する。 これらの仮定の下, 建物重量は第 1 層 $570 \mathrm{kN}$, 第 2 層 $700 \mathrm{kN}$ である。

\section{2 構造階高}

構造階高は各階の梁天間の高さとし, 1 階を基礎立ち上がり壁天端 から 2 階梁天端までの $3,755 \mathrm{~mm}, 2$ 階を 2 階梁天端から小屋梁天端 までの $3,567 \mathrm{~mm}$ とする。

\section{3 復元力特性の仮定とその検証}

図 2 の軸組図から復元力特性を計算する。耐震要素は筋かいと外 壁のラスモルタルとする。筋かいには端部金物がないため, 圧縮筋か いのみを考慮する。したがって, 正加力時と負加力時を分けて復元力 特性を計算することになるが, 後述の常時微動計測結果と比較する ために, 加力方向を考慮しない場合についても計算する。なお, 筋か い断面は $50 \mathrm{~mm} \times 150 \mathrm{~mm}$ であるが，ここでは 2 つ割り筋かいの復元 力特性を採用した。得られた $X, Y$ 方向の復元力特性を図 8(a),(b)に示 す。これに対応する降伏耐力, 降伏せん断力係数をそれぞれ表 4,5 に 示し, 同表には加力方向を無視した場合（両方向）も併記する。

図 8, 表 4,5 より, 当該建物の保有水平耐力は極めて低く, ベース シア係数にして 0.032〜0.050 しかないことが分かり, 現行法におけ る中地震に対する必要ベースシア係数 $0.18(Z=0.9$ 考慮) を満足し ない。 $X, Y$ 方向では, 建物長辺方向である $Y$ 方向が短辺方向である $X$ 方向に比べて耐力が高い。このことは, 前述の常時微動計測結果から も明らかである。

建物を, 2 階が剛体で $X, Y$ 方向に独立した 1 自由度系と仮定し, 計 
測された 1 次固有振動数が, その 1 自由度計の固有振動数に対応す ると考える。常時微動計測による $X, Y$ 方向の固有振動数比は 3.05/2.42=1.26である。他方, 微動であることを考慮し, 筋かいの圧 縮側, 引張側を無視したときのベースシア係数（表 5 中の両方向）の 比の平方根は $\sqrt{0.069 / 0.040}=1.31$ である。 $X, Y$ 方向の降伏変形角は 等しいので, 振動数比とベースシア係数比は比較して見ることがで る。両者の誤差は精々 $4 \%$ であり，よく合っていると言える。

つぎに，建物を $X ， Y$ 方向に独立した 2 自由度計と仮定する。 1,2 階 の降伏変形角は等しい。 1,2 階の固有ベクトル比を $u_{2} / u_{1}=2$ と仮定 すると，剛性比と耐力比は比較して見ることができる。この仮定の下， 1,2 階の降伏耐力比 $Q_{2} / Q_{1}$ を求めると, $X$ 方向 $58.0 / 50.6=1.15, Y$ 方向 81.6/87.1=0.94 であり, 階高の違いを考慮して剛性比 $k_{2} / k_{1}$ にすると, $X$ 方向 $1.20, Y$ 方向 0.99 である。常時微動計測から得られた $X, Y$ 方向 の並進に関する 1 次, 2 次固有振動数, 建物質量を 2 質点系の固有方 程式に代入し, 剛性比 $k_{2} / k_{1}$ を求めると, $X$ 方向 $1.27, Y$ 方向 1.19 で あった。この仮定の下では, 復元力特性の計算結果と常時微動計測の 誤差はX方向 $9 \%, Y$ 方向 20\%である。他方, 固有方程式から固有心゙ クトル比を求めると， $X, Y$ 方向それぞれ 1.51,1.55 であり，常時微動 の剛性比からは耐力比を過小評価していることになり，誤差は更に $1.3(=2 / 1.51)$ 倍程度に大きくなる。

このように, 常時微動計測は 2 階床だけで実施したにも関わらず, いくつかの仮定を設定することで， $X, Y$ 方向の 1 次固有振動数比, 1 次と 2 次の固有振動数比から, 仮定した水平耐力の妥当性を検証す ることができた。これは，対象建物が現代的な木造住宅と異なり，建 具や仕上げ材の常時微動への寄与が低いためと思われ，文化財建築 物の耐震診断時における常時微動計測の有用性を示寸知見である。

他方, 得られた知見は相対的なものであって, 絶対的なもの, 寸な わち，耐力の大小を直接的に判断する材料にはなっていない。耐力の 大きさは 1 次固有振動数と耐力の相関を考慮する必要がある。本研 究対象の建築物の 1 次固有振動数は低く, 耐力も低いことが予測さ れ, 事実, 降伏せん断力係数も極めて低かった。また, 各階, 各方向 の降伏変形角が等しく, 上下階が同時に降伏する固有べクトルを仮 定した。建物形状や壁量から，明らかに実状がこの仮定に合わない場 合には，剛性比と耐力比を直接結び付けることはできない。

なお， 1 階の偏心率は $X$ 方向 $0.228, Y$ 方向 0.073 であり, 構造設計 上の上限值 0.30 には達していないので，偏心によるねじれの影響は 設計上無視した ${ }^{21)}$

\section{4 耐震性能評価結果とその考察}

前述の地盤条件, 重量, 復元力特性, 構造階高を用い, 損傷限界時 と安全限界時の最大変位応答を限界耐力計算により求める。縮約 1 自 由度系の復元力特性と必要耐力曲線を方向別，加力方向に図 9(a) (d) に示寸。図中の復元力特性と必要耐力曲線の交点から求めた応答 変形角を表 6 に示す。同表には，応答が得られたときの等価周期 $T$ と 等価粘性減衰定数 $h$ も示寸。図表より, 損傷限界時において, 建物方 向, 加力方向に関わらず， 1 階の変形角がクライテリアである 1/120rad を超えることが分かり, 最大で 45\%超過している。安全限 界時においては, 変形が過大になって応答が求まらない。

この結果は, 耐力不足に起因することは明らかである。根本的な理 由は壁量不足であるが，筋かいの壁長に対する階高の比が 3.5 を超 え, 一般の筋かい壁の適用範囲を超えていること, 筋かい角度により
水平耐力の補正は施しているものの, 角度が大きいために水平力負 担を期待できないこと，筋かい端部に金物が取り付いていないため 引張時の耐力負担を期待できないこと, 等も挙げられる。さらに, 筋 かい断面は $50 \mathrm{~mm} \times 150 \mathrm{~mm}$ であり，標準の 2 つ割り筋かいよりも大 きいはずであるが，一般の 2 つ割り筋かいとして評価していること もある。実験による検証が望まれるが，これは今後の課題としたい。

\section{6. 耐震補強の概算}

所要の耐震性能を満足させるための耐震補強の概算を行う。補強 方針を次のように設定する。

屋根の蕞き土を撤去し，栈瓦に変更することで建物の軽量化を図 る。耐力壁位置は現況通りとするものの，筋かい断面を $105 \mathrm{~mm} \times 105 \mathrm{~mm} （ X$ 方向 1 階のみ $120 \mathrm{~mm} \times 120 \mathrm{~mm}$ ）に変更すること で，水平耐力を増大寸る。なお，筋かい端部は金物で補強し，圧縮・ 引張力とも負担できるようにし，水平構面に剛床を仮定できるよう な補強を施すことを前提とする。

計算すると, 屋根荷重は現況の $2.40 \mathrm{kN} / \mathrm{m}^{2}$ から $1.30 \mathrm{kN} / \mathrm{m}^{2}$ に減り, 第 2 層の重量は $450 \mathrm{kN}$ となる。筋かい壁の耐力については，無等級 スギの圧縮に関する基準強度を用いて文献 21)により座屈耐力を求

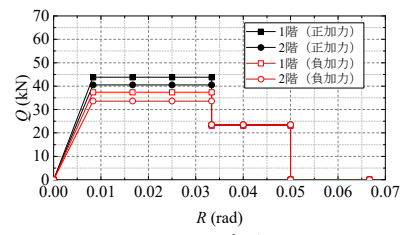

(a) $X$ 方向

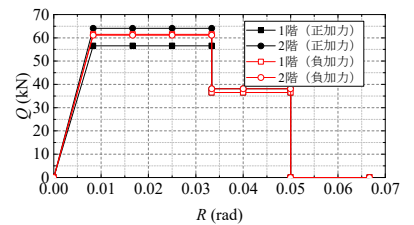

(b) $Y$ 方向
図 8 復元力特性

\begin{tabular}{|c|c|c|c|c|}
\hline 方向 & 階 & 正加力時 & 負加力時 & 両方向 \\
\hline \multirow{2}{*}{$X$ 方向 } & 2 & 43.8 & 37.4 & 58.0 \\
\hline & 1 & 40.5 & 33.6 & 50.6 \\
\hline \multirow{2}{*}{$Y$ 方向 } & 2 & 56.6 & 61.5 & 81.6 \\
\hline & 1 & 64.1 & 61.1 & 87.1 \\
\hline \multicolumn{5}{|c|}{ 表 5 降伏せん断力係数 } \\
\hline 方向 & 階 & 正加力時 & 負加力時 & 両方向 \\
\hline \multirow{2}{*}{$X$ 方向 } & 2 & 0.063 & 0.053 & 0.083 \\
\hline & 1 & 0.032 & 0.026 & 0.040 \\
\hline \multirow{2}{*}{$Y$ 方向 } & 2 & 0.081 & 0.088 & 0.117 \\
\hline & 1 & 0.050 & 0.048 & 0.069 \\
\hline
\end{tabular}

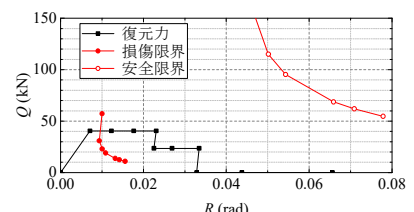

(a) $X$ 方向正加力時

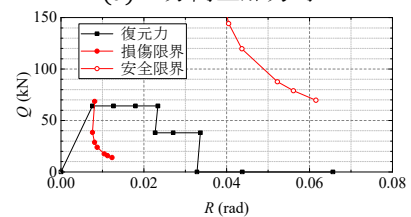

(c) $Y$ 方向正加力時

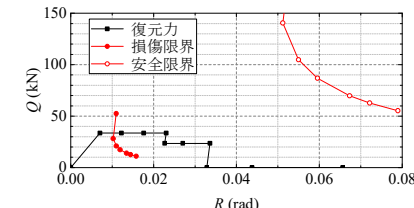

(b) $X$ 方向負加力時

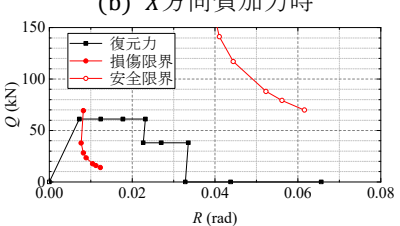

(d) $Y$ 方向負加力時
図 9 縮約 1 自由度系の復元力特性と必要耐力曲線

\begin{tabular}{|c|c|c|c|c|c|}
\hline & & \multicolumn{2}{|c|}{$X$ 方向 } & \multicolumn{2}{|c|}{$Y$ 方向 } \\
\hline & & 正 & 負 & 正 & 負 \\
\hline \multirow{3}{*}{ 損傷限界 } & 2 2 階 & $1 / 184$ & $1 / 152$ & $1 / 195$ & $1 / 174$ \\
\hline & 1 階 & $1 / 83$ & $1 / 112$ & $1 / 91$ & $1 / 105$ \\
\hline & $T, h$ & $2.81 \mathrm{~s}, 0.099$ & $3.08 \mathrm{~s}, 0.100$ & $2.00 \mathrm{~s}, 0.065$ & $2.02 \mathrm{~s}, 0.066$ \\
\hline \multirow{2}{*}{ 安全限界 } & 2 階 & - & - & - & - \\
\hline & 1 階 & - & - & - & - \\
\hline
\end{tabular}




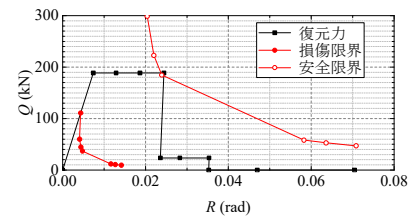

(a) $X$ 方向

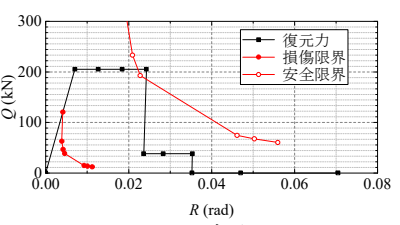

(b) $Y$ 方向
図 10 補強後の復元力特性と必要耐力曲線

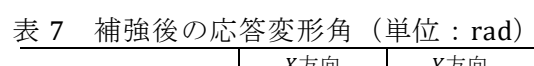

\begin{tabular}{c|c|c|c}
\hline \multicolumn{2}{c|}{} & $X$ 方向 & $Y$ 方向 \\
\hline \hline \multirow{3}{*}{ 損傷限界 } & 2 階 & $1 / 302$ & $1 / 382$ \\
\cline { 2 - 4 } & 1 階 & $1 / 204$ & $1 / 204$ \\
\cline { 2 - 4 } & $T, h$ & $0.93 \mathrm{~s}, 0.050$ & $1.88 \mathrm{~s}, 0.050$ \\
\hline \multirow{3}{*}{ 安全限界 } & 2 階 & $1 / 209$ & $1 / 254$ \\
\cline { 2 - 4 } & 1 階 & $1 / 31$ & $1 / 33$ \\
\cline { 2 - 4 } & $T, h$ & $1.70 \mathrm{~s}, 0.162$ & $1.56 \mathrm{~s}, 0.160$ \\
\hline
\end{tabular}

め, 水平力に換算する。復元力特性は $1 / 120 \mathrm{rad}$ を折点とした完全弾 塑性型とした。

以上の補強により, ベースシア係数は $X, Y$ 方向についてそれぞれ $0.185,0.201$ に増大寸る。補強後における縮約 1 自由度系の復元力特 性と必要耐力曲線を方向別に図 $10(a),(b)$ に示し, 各階の応答変形角 を表 7 に示す。図表より, 各階, 各方向とも損傷限界時 $1 / 120 \mathrm{rad}$ 以 下, 安全限界時 1/30rad 以下を満足する。

\section{7.おわりに}

本研究では, 重要文化財の擬洋風建築物の耐震性能評価を行った。 調査が限定され，構造計算上の不明な点を仮定せざるを得ない条件 の下, 常時微動計測結果を活用し, 不明な点を明瞭するための手法に ついて検討し，その有効性を示した。得られた知見を以下に示す。

1. 地盤の H/Vスペクトル比にはピークが明瞭に認められなかったも のの, 最大值をとる振動数が卓越振動数である可能性が高いと判断 し，この場合，当該敷地は第二種地盤に該当した。他方，地震八ザ 一ドステーションによると第一種地盤に該当しており,両者に乘離 があった。両者の結果から,ここでは第一種地盤であると判断した。

2. 常時微動計測により，固有振動数を同定したところ， $X, Y$ 方向 1 次固有振動数はそれぞれ $2.42 \mathrm{~Hz}, 3.05 \mathrm{~Hz}$ であって，類似した建築 物の固有振動数と比較すると下限の方に位置していた。また, 振動 モードを同定し, 床面の剛性が低いこと, ねじれ振動が生じている ことを変位波形から確認した。

3. 粘性減衰定数は 0.03 であった。RD 法ではなくフィルター処理し た波形の自己相関関数から求めたが，評価は十分に可能である。

4. 常時微動計測は 2 階床だけで実施したものの, $X, Y$ 方向の 1 次固 有振動数比, 1 次と 2 次の固有振動数比から, 各階, 各方向に仮定 した復元力特性が妥当であることを示した。この手法は簡易であり， 常時微動計測を文化財建築物の耐震診断に用いることの有効性を 示すものであり, 本研究における重要な知見である。他方, 一般に は剛性比と耐力比は直接結び付くものではなく, 建物形状や壁量か ら，1,2 階の降伏変形角が等しく，かつ 1,2 階で同時に降伏する変 位モードを予測できる場合に適用できると考える。

5. 限界耐力計算の結果, 調查対象建物の保有水平耐力は低く, 所要 の耐震性能を具備しないことが確認できたが, 計測による固有振動 数が低かったことは，この結果を支持するものとなっている。

\section{謝辞}

本研究の遂行にあたり，広島県府中市教育委員会から資料を提供 して頂きました。また, 調査に際し, ご協力頂きました同教育委員会, 有限会社徳岡工務店, 福山大学工学部建築学科山田研究室の諸学生 にお礼申し上げます。

\section{参考文献}

1) 角陸順香, 清家剛, 藤田香織, 宇野繕晴: 木造重要文化財建築物の耐震補強 における意思決定プロセスに関する研究一構造設計者の役割を中心として 一，日本建築学会計画系論文集，No. 590 号，pp. 65-72，2005.4

2) 濱健太郎, 向井洋一: 伝統的木造建築物の微振動計測に基づく構造特性の評 価に関する研究, 日本地震工学会論文集, 第 16 巻, 第 8 号 (特集号), pp. 110122, 2016

3) 海原英正, 向井洋一: 伝統的構法による木造建築物の改修過程における常時 微動特性評価に関寸る研究, 日本建築学会近畿支部研究発表会報告集, pp. 245-248, 2012. 6

4) 杉野未奈, 多磯山法子, 大西良広, 林康裕 : 固有振動数の振幅依存性に基づ く伝統木造建物の最大応答予測法, 日本建築学会構造系論文集, 第 77 巻, 第 672 号, pp. 197-203，2012.2

5) 田淵千夏子, 大橋好光 : 微動測定とその耐震診断への応用の可能性一木造建 築物の耐震診断法に関する研究その 2-, 日本建築学会構造系論文集, 第 616 号, No. 616, pp. 141-147, 2007.6

6) 柳沢泰男, 田淵千夏子, 大橋好光 : 既存木造軸組構法住宅の耐震性評価の精 度向上のための常時微動の活用に関する研究一実測値と理論值の関係一, 日 本建築学会技術報告集, 第 13 巻, 第 25 号, pp. 59-64, 2007.6

7) 西塔純人, 北倉友佳, 更谷安紀子, 林康裕: 微動計測を用いた既存木造軸組 構法住宅の簡易耐震性能評価に関する研究, 日本建築学会技術報告集, 第 22 巻，第 50 号, pp. 61-65, 2016.2

8) 南部恭広, 杉野未奈, 小林素直, 多幾山法子, 渡辺千明, 林康裕: 奈良県五 條市新町における伝統木造住宅の現地調查と耐震性能評価, 構造工学論文集, 62B 巻, pp. 251-258, 2016. 3

9) 南部恭広, 横部達也, 多幾山法子, 渡辺千明, 林康裕 : 和歌山県湯浅町にお ける伝統木造家屋の耐震性評価, 日本建築学会技術報告集, 第 19 巻, 第 43 号, pp. 909-912, 2013. 10

10) 朝ティリ, 袋早希, 古川忠稔, 青木孝義 : 大正時代に建てられた木造住宅 の耐震改修に伴う振動特性の変化の評価, 日本建築学会東海支部研究報告集, 第 52 号, No235, pp. 225-228, 2014. 2

11) 藤井智規, 福和伸夫, 千賀英樹, 飛田潤, 吉田明義 : 常時微動計測による博 物館明治村の近代建築物の振動性状データベース構築, 日本建築学会技術報 告集，第 13 巻，第 25 号, pp. 59-64, 2007.6

12) 敷田人美, 上野幸夫, 濱田文仁, 山田幸宏, 稲葉實, 若島嘉朗, 上田邦成, 泰正徳: 重要文化財 岩手大学農学部 (旧盛岡高等農林学校) 旧本館耐震対 策, 日本建築学会北陸支部研究報告集, pp. 172-175, 第 57 号, 2014.7

13) 藤井智規, 石川新太郎, 福和伸夫, 飛田潤 : 重要文化財 - 旧三重県庁舎の耐 震補強と常時微動計測による建物振動特性の変化の確認, 日本建築学会大会 学術講演梗概集 (中国), 構造III, pp. 61-62, 2008.9

14) 大町達夫, 紺野克昭, 遠藤達哉, 年縄巧 : 常時微動の水平動と上下動のス ペクトル比を用いる地盤周期推定方法の改良と適用，土木学会論文集， No. 489/ I -27, pp. 251-260, 1994. 4

15) 日本建築学会 : 建築物の減衰, 2000.10

16) 鈴木祥之, 中治弘之, 平山貴之, 秋山真一：常時微動計測による木造住宅 の振動特性, 日本建築学会大会学術講演梗概集, C-1 巻, pp. 221-222, 1998.9 17) 岩井哲, 一反田康啓 : 木造建物の動的解析モデル構築のためのデータベー ス, 日本建築学会大会学術講演梗概集, C-1 巻, pp. 289-290, 1999.9

18）（一社）日本建築構造技術者協会関西支部：伝統的な軸組構法を主体とし た木造住宅・建築物の耐震性能評価・耐震補強マニュアル (第 2 版), 2014.4 19）（一財）日本建築防災協会：2012 年改訂版 木造住宅の耐震診断と補強方 法 例題編・資料編, 2013.5

20) 文化庁：重要文化財（建造物）而震基礎診断実施要領，2012 年改訂 21）日本建築学会: 限界耐力計算による伝統木造建築物構造計算指針・同解説, 2013.2

22) 日本建築学会 : 木質構造設計規準 - 同解説一許容応力度 - 許容耐力設計法, 2011. 3

[2019 年 1 月 8 日原稿受理 2019 年 5 月 14 日採用決定 $]$ 